\title{
Identitet $\mathrm{i}$ vrijednosti. Sociološka studija o hrvatskom društvu
}

\section{Politička kultura, 2014., Zagreb, 356 str.}

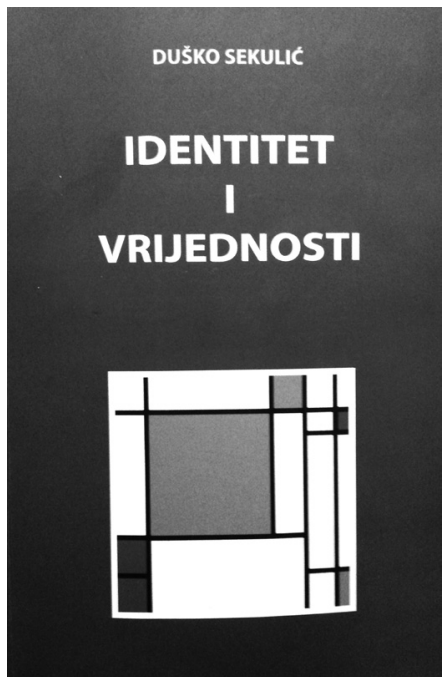

Knjiga Identitet $i$ vrijednosti Duška Sekulića sadrži analize opsežnih empirijskih istraživanja provedenih tijekom 26 godina, u kojima je hrvatsko društvo prošlo kroz korjenite političke, ekonomske i sociokulturne transformacije. Istraživanja su provođena tijekom krize socijalizma, uvođenja demokratskog sustava, rata i perioda tranzicije, odnosno 1984./1985., 1989./1990., 1996., 2004. i 2010. godine na reprezentativnim uzorcima stanovništva Hrvatske. Uz navedene baze podataka autor se za tematske potrebe pojedinih poglavlja služio i podacima koji su prikupljeni u različitim kvantitativnim istraživanjima tijekom 1995. g., 2003./2004. g te 2006. g. i na taj je način upotpunio sliku slojevitih i složenih promjena koje su zadesile društvenu zbilju Hrvatske. Knjiga se, kako autor navodi, prvenstveno bavi identitetom i vrijednosnim orijentacijama od 2000ih do 2010. g., čime zapravo predstavlja treću studiju u nizu (prve dvije knjige su Strukture na izmaku iz 1991. g. i Sukob i tolerancija: O društvenoj uvjetovanosti nacionalizma i demokracije iz 2004. g.) u kojoj prati promjene strukture i vrijednosnih orijentacija. Ova opširna studija, uz uvod i sažetak, sadrži jedanaest poglavlja, koja su podijeljena u tri glavna tematska bloka naziva „Identitet“, „Vrijednosti“ i „Sukobi“.

Prvi dio knjige, „Identitet“, sadrži tri poglavlja: „Sociologija etničkog identiteta“, „Građanski i etnički identitet: slučaj Hrvatske“, „Europski i hrvatski identitet“. Poglavlje „Sociologija etničkog identiteta“ teorijskog je karaktera te analizira shvaćanja i značenja fenomena etniciteta, rase i nacije te njihovo funkcioniranje u s jedne strane svakodnevnoj praksi i s druge strane znanstvenoj primjeni tih pojmova. Ti fenomeni socijalni su konstrukti, smatra autor, koji ne sadrže zadane i nepromjenjive karakteristike, već su produkt različitih procesa socijalne konstrukcije. U tom smislu stanovište je autora da se zadatak sociologije ne nalazi u jasnom definiranju tih fenomena i isticanju njihovih međusobnih distinkcija, već u konceptualnom razvoju od esencijalističkog prema konstruktivističkom sociološkom shvaćanju nacije, etniciteta i rase. Ti fenomeni zapravo su u stalnom procesu redefiniranja posredstvom povije- 
sno-političkih procesa. Konceptualni razvoj koji to odražava Sekulić naznačuje kao kontinuitet teorijskih koncepata od Webera preko Bartha do Brubackera. Pritom svoju teorijsku analizu primjenjuje na hrvatsku realnost, odnosno sociopovijesnu i sociopolitičku uvjetovanost stvaranja hrvatskog identiteta na primjeru poimanja nacionalne kulture, poglavito jezika kao važnog elementa u stvaranju nacije. Sekulić, koristeći Weberov konceptualni aparat, pobija mit o porijeklu hrvatske nacije (postojanje zajedničkih predaka, hrvatskog gena i sl.) analizirajući političke i povijesne procese u podlozi odabira specifičnih elemenata kulture koji postaju granica prema drugima i temelj zatvaranja, odnosno socijalne integracije. Tako nacionalni jezik kao važan element kulture ne predstavlja temelj za izgradnju hrvatskog etnikuma - proces stvaranja hrvatskog etnikuma usmjerava stvaranje hrvatskog jezika. Stoga autor smatra da valja osvijestiti historijske i druge okolnosti koje imaju ulogu nezavisnih varijabli u oblikovanju nacionalnog identiteta kao zavisne varijable. U tom smislu, na tragu Brubackerovog pristupa, predlaže da se u analitičke svrhe umjesto identiteta upotrebljava „identifikacija“ i „kategorizacija“ jer bolje odražavaju promjenjivost i ovisnost identiteta o kontekstu. Identifikacije pojedinca slabe i jačaju, pri čemu mogu mijenjati poziciju na hijerarhiji identifikacija, a autor, sukladno napomenutoj konstruktivističkoj poziciji, smatra da je sociološki relevantno analizirati procese koji dovode do prihvaćanja neke primarne identifikacije, njene transformacije u neku drugu ili pak do njezinog potpunog nestajanja. Tako i na društvenoj razini „grupnost“ analitički nije fiksna kategorija, ona je varijabla, što znači da može slabiti ili jačati tijekom vremena, a u podlozi njezine (re)konstrukcije nužno je uzeti u obzir sadržaj, karakter i formu socijalnih i političkih silnica koje ju oblikuju, tumače i promoviraju. Potom analizira postavke esencijalizma i konstruktivizma u shvaćanju kolektivnog identiteta te za primjere navodi Kaleov i Huntingtonov pristup. Kritizira Kaleovo linearno shvaćanje povijesti i projekciju današnjih shvaćanja u prošlost, uz što se vezuje esencijalističko razumijevanje hrvatskog identiteta kao stalnog i nepromjenjivog u vremenu i prostoru.

Temu konstrukcije hrvatskog nacionalnog identiteta u njegovoj etničkoj/primordijalnoj i građanskoj varijanti autor pomnije analizira u poglavlju „Građanski i etnički identitet: slučaj Hrvatske“. Razlikovanje „zapadnih“ ili građanskih i „istočnih“ ili etničkih nacionalizama H. Kohna (1961.) Sekulić pretvara u kontinuum s građanskim i etničkim polom. Drugim riječima, individualni etnički identitet može više naginjati građanskom ili etničkom obliku. Na taj način istražuje dinamiku i odrednice jugoslavenskog identiteta (koji se u doba Jugoslavije nije naročito ohrabrivao) i njegovog funkcionalnog ekvivalenta - građanskog identiteta u postjugoslavenskoj Hrvatskoj. Naime autor postavlja i potvrđuje hipotezu da je građanski identitet u Hrvatskoj postao funkcionalni ekvivalent nestajućem jugoslavenstvu, pri čemu su motivacije u smjeru izražavanja „građanskog“ nasuprot „etničkom“ identitetu iste kao i one u slučaju izražavanja jugoslavenstva nasuprot etničkom identitetu.

U poglavlju „Europski i hrvatski identitet: kognitivna mobilizacija ili latentni konflikt“ Sekulić potvrđuje hipotezu da se ljudi generalno osjećaju bližima nacionalnoj nego nadnacionalnim razinama, kao što su jugoistočna Europa ili Europa, ali i da nacionalna i nadnacionalna vezanost pripadaju različitim dijelovima „ideološkog prostora" (str. 113). Naime osobe tradicionalne i nacionalističke orijentacije iskazuju veću 
nacionalnu vezanost, a osobe koje zastupaju kozmopolitske i proeuropske ideje izražavaju snažniju nadnacionalnu vezanost, dok strukturne varijable imaju nisku prediktorsku moć.

Autor se vrijednostima bavi u drugom dijelu knjige te u poglavlju „Društveni okvir i vrijednosni sistem" razlaže glavne modernizacijske teorije u Jugoslaviji, odnosno u Hrvatskoj tijekom socijalizma. Oslanja se na mnogobrojne modernizacijske teorije, no važno mjesto zauzima Županovljeva teorija vrijednosti jugoslavenskog/hrvatskog društva te pritom daje pregled razvoja njegove teorijske misli i prikaz diferenciranja vrijednosnih dimenzija kroz vrijeme. Naime Županov postupno izdvaja autoritarnost naspram pluralizma kao sve važniju odrednicu vrijednosne orijentacije, što Sekuliću predstavlja osnovu za konstrukciju teorijskog modela. Sekulić, uz Inglehartove postavke modernizacijske teorije, također koristi Supekovu dihotomiju revolucija - normalizacija te smatra da je njegova shema klasne revolucije primjenjiva i na analizu nacionalne revolucije, koja je potisnula onu klasnu.

U poglavlju „Socijalizam i nacionalizam kao društveni okviri“ autor iscrpno analizira dinamiku i način strukturiranja glavnih vrijednosnih orijentacija u socijalističkom i postsocijalističkom periodu, od kojih je prvi obilježen socijalizmom, a drugi nacionalizmom kao temeljnom ideološkom orijentacijom. Kada je riječ o postsocijalističkoj Hrvatskoj, polazi od hipoteze retradicionalizacije i od hipoteze prihvaćanja liberalnih vrijednosti uz istovremeno opadanje autoritarnih vrijednosti. Hipoteza o retradicionalizaciji dijelom je potvrđena s obzirom da su neki njezini elementi ojačali - intenzitet religioznosti i nacionalnog ekskluzivizma, koji je najprihvaćeniji 1996. g. i ostaje stabilan u zoni prihvaćanja do 2010. g., dok prihvaćanje rodnog konzervativizma u istom periodu slabi. Međutim, iako su pred sam slom socijalizma liberalne vrijednosti (ekonomsko-političkog liberalizma) visoko prihvaćene, one tijekom vremena ne ostaju očekivano stabilne, već uslijed razočaranja novim ekonomskim i političkim poretkom bivaju sve manje prihvaćene. Pritom raste prihvaćanje političkog autoritarizma, a posebno nakon 2000. g. Detaljna analiza dinamike liberalnih vrijednosti nalazi se u poglavlju „Liberalne vrijednosti od socijalizma do postsocijalizma“. Osim toga autor analizira i determinante prihvaćanja ili odbijanja liberalnih principa, pri čemu se najviše ističe religioznost, koja tumači vrijednosne promjene, međutim ne jednoznačno u svakom ispitivanom periodu. Problematizirajući ulogu religioznosti, Sekulić zaključuje da se smjer i intenzitet utjecaja religioznosti na prihvaćanje liberalne orijentacije mijenja s obzirom na dominaciju određene ideologije u društvu. U socijalističkom periodu, kada je bila dio, kako kaže, „opozicione' ideologije“, religioznost je predstavljala snažan prediktor liberalne orijentacije. Promjenom društvenog sustava i jačanjem pozicije religije u dominantnom vrijednosnom sklopu njezin se utjecaj također mijenja, pa tako iako ostaje povezana s prihvaćanjem privatnog vlasništva, nereligioznost se više vezuje uz prihvaćanje višestranačkog sustava. Religioznost se kao pojava pokazuje zanimljivom za daljnju analizu, stoga joj autor posvećuje cijelo jedno poglavlje. Sekulića ne zanima samo analiza porasta religioznosti već i njezina uloga i značaj u vrijednosnom sustavu pojedinca, ali i društva u cjelini. Paralelno s jačanjem religioznosti u svim njezinim elementima njezina je prediktivna snaga u određivanju vrijednosnih orijentacija oslabila, štoviše, prema nalazima autora porast religioznosti sve je slabije povezan s drugim 
vrijednosnim orijentacijama (iako su i 2010. religiozniji ujedno nacionalno ekskluzivniji, rodno konzervativniji i autoritarniji) i religioznost postaje sve manje ovisna o drugim vrijednosnim kretanjima, a sve više posebna vrijednosna dimenzija. Ipak u postsocijalističkom periodu jača povezanost religioznosti s političkim autoritarizmom. Ukupno jačanje religioznosti i njezino sve izraženije vezivanje uz politički autoritarizam te istovremeno slabljenje religioznosti kao podloge ostalim vrijednosnim orijentacijama autor objašnjava procesom socijalnog konformiranja - „biti religiozan u socijalizmu nije bio indikator konformizma jer je na neki način izražavalo protest protiv postojećeg režima. Biti religiozan danas znači konformizam (politički autoritarizam) jer znači prilagođavanje postojećem režimu i prevladavajućem javnom mnijenju." (str. 236).

Treći dio knjige, „Sukobi“, započinje poglavljem „Nacionalni ekskluzivizam i etnički konflikt", u kojem polazi od hipoteze suprotne teoriji etničke mržnje te zastupa stanovište da je nacionalni ekskluzivizam, odnosno netolerancija posljedica a ne uzrok ratnih dešavanja. Hipotezu potvrđuje uspoređujući stupanj nacionalnog ekskluzivizma prije i poslije sukoba - 1996. g. bio je najprihvaćeniji, a 1989. g., pred rat, bio je u sferi odbijanja. Zatim raspravlja o utjecaju brojnih mobilizacijskih procesa koji oblikuju društvenu normalizaciju nacionalnog ekskluzivizma, odnosno doprinose da niz elemenata nacionalne isključivosti postane samorazumljiv i društveno prihvatljiv. Ključnu ulogu u tom procesu pripisuje interakciji između političkih vođa, intelektualaca, medija te različitih opinion-makera, kojom se proizvodi masovna propaganda i opća javna slika o drugome. Masama se, dakle, posreduju iskustva s „onima drugima“, čime se u krajnjoj instanci utječe na individualne reinterpretacije i redefinicije osobnih odnosa i stavova prema pripadnicima prethodno negativno portretirane suprotstavljene grupe.

Poglavlje „Etnicitet u komparativnoj i historijskoj perspektivi“ sadrži kritiku široko prihvaćenog mita o etničkoj mržnji, koji pretpostavlja da u podlozi umjetno stvorene i narodima nametnute Jugoslavije vrije ukorijenjena „drevna“ nacionalna mržnja i netrpeljivost. Prikazujući dinamiku nacionalnog ekskluzivizma Sekulić zaključuje da nacionalna isključivost po republikama bivše Jugoslavije nije bila visoka prije samih sukoba, već da takvi stavovi rastu kao posljedica nasilja. Također, autor se studiozno bavi kompleksnom temom odnosa etničke netolerancije i heterogenosti u Jugoslaviji pred sam početak krvavih sukoba koristeći kontaktnu hipotezu G. Allporta i hipotezu prijetnje H. Blalocka te miješani model D. E. Forbesa, raspravljajući o ulozi kulturne distance, demografskih promjena, odnosno stabilnosti etničkih proporcija za etnički animozitet. Uvjerljivo razlaže faktore etničke (ne)tolerancije, međutim smatra da nijedan od njih ne može objasniti razloge izbijanja etničkih sukoba. Time dodatno nalazi argument za odbacivanje često primjenjivane teorije o etničkoj mržnji u pokušaju objašnjenja izvora sukoba u Jugoslaviji. S druge strane, prezentirani istraživački nalazi jasno ukazuju da ratni sukob neovisno o uzroku ima negativan utjecaj na etničku toleranciju u poslijeratnom području.

U poglavlju „Autoritarna dinamika“ autor se služi Blumerovim teorijskim okvirom etnomobilizacije kao kolektivnim procesom u kojem presudnu ulogu pripisuje utjecaju političkih i drugih elita, koje svojim istupima u velikoj mjeri formiraju etnički i 
nacionalno isključiv javni diskurs. Pa se tako sa znanstvenih stranica preuzima i proširuje rasni diskurs o „genocidnosti Hrvata“ (Krestić) s jedne strane i o Srbima vođenima „prirođenim rasnim prohtjevom za prisvajanjem [...] manijom za uništavanjem i rastvaranjem [...]" (Pilar) (str. 298). Također, u toj raspravi primjenjuje pristup R. Petersona, koji naglašava važnost sentimenta ogorčenosti položajem vlastite grupe, koji je posebno vidljiv uslijed, primjerice, promjene političkih granica. Takvo tinjajuće nezadovoljstvo i osjećaj eksploatiranosti jednog naroda od drugog ili drugih, bilo unutar pojedine republike bilo u okviru Jugoslavije, predstavljao je kvalitetan instrument za masovnu mobilizaciju. Pritom je u toj mobilizaciji opet važnu ulogu imala elita, kako politička tako i intelektualna te medijska, zaključuje autor.

Knjiga Vrijednost $i$ identitet Duška Sekulića doista je najbolje opisati podnaslovom: sociološka studija o hrvatskom društvu. Radi se o važnom i vrlo vrijednom sociološkom djelu koje se studiozno bavi ne samo dinamikom i strukturom vrijednosnih orijentacija te njihovih determinanti tijekom gotovo triju desetljeća obilježenih socijalnim, političkim i ekonomskim potresima u Hrvatskoj već i mnogim dimenzijama društvenog konteksta koje su utjecale na takvu dinamiku i strukturu vrijednosti. Stoga ovo djelo predstavlja izuzetnu vrijednost za hrvatsku sociologiju, posebno uzevši u obzir fragmentiranost bavljenja vrijednostima u nas. 